\title{
Manajemen Pendidikan Nilai-Nilai Multikultural dalam Pembentukan Karakter Religius Siswa di MAN Yogyakarta III tahun Pelajaran 2016/2017
}

\author{
Hanik Baroroh \\ UIN Sunan Kalijaga Yogyakarta \\ han.baroroh@gmail.com
}

\begin{abstract}
ABSTRASK
Fokus kajian pada penelitian ini dilatar belakangi dari munculnya berbagai bentuk kekerasan yang cukup beragam di sekolah yang timbul karena adanya keberagaman yang terjadi antar siswa dalam berbagai hal, sehingga sangat diperlukan adanya pendidikan nilai-nilai multikultural dalam pembentukan karakter religius yang melibatkan serangkaian proses manajemen di sekolah. Tujuannya yaitu untuk mewujudkan siswa menjadi manusia yang beriman dan bertakwa kepada Tuhan Yang Maha Esa, berakhlak mulia, dan menjadi warga negara yang demokratis serta bertanggung jawab. Hasil penelitian ini menunjukkan bahwa yang pertama, dalam pelaksanaan manajemen pendidikan nilai-nilai multikultural di MAN Yogyakarta III meliputi empat tahap, yaitu perencanaan yang dilaksanakan melalui tiga proses, pengorganisasian yang terdiri dari dua kelompok, penggerakan yang terdiri dari dua bentuk penggerakan, dan pengawasan yang dibagi menjadi dua bentuk pengawasan. Kedua, implementasi nilainilai pendidikan multikulural dalam pembentukan karakter religius dilakukan melalui tiga proses yaitu kegiatan rutin yang diterapkan melalui tiga kegiatan, kegiatan spontan yang diadakan pada waktu tertentu, dan pengondisian yang diterapkan melalui berbagai tulisan yang memotivasi.
\end{abstract}

Kata Kunci: Manajemen Pendidikan, Pendidikan Nilai-nilai Multikultural, Pembentukan Karakter Religius

\section{A. PENDAHULUAN}

Manajemen dalam dunia pendidikan dapat didefinisikan sebagai seni dan ilmu mengelola sumber daya pendidikan untuk mewujudkan suasana belajar dan proses pembelajaran agar peserta didik secara aktif mengembangkan potensi dirinya untuk memiliki kekuatan spiritual keagamaan, pengendalian diri, kepribadian, kecerdasan, akhlak mulia, serta ketrampilan yang diperlukan dirinya, masyarakat, bangsa dan negara. ${ }^{1}$ Jadi, manajemen dalam dunia pendidikan sangat diperlukan, karena bertujuan untuk mewujudkan tujuan pendidikan dan tujuan sekolah, yang mengacu kepada visi dan misi sekolah, dan dilakukan oleh manajer atau pimpinan sekolah dan tenaga

\footnotetext{
${ }^{1}$ Husaini Usman, Manajemen: Teori Praktik dan Riset Pendidikan Ed. 2 (Jakarta: Bumi Aksara, 2008), hlm. 9.
} 
kependidikan. ${ }^{2}$ Hal tersebut dapat diwujudkan melalui serangkaian proses manajemen yang terdiri dari empat tahap, yakni perencanaan, pengorganisasian, penggerakkan, dan pengawasan.

Salah satu upaya untuk mewujudkan tujuan pendidikan yaitu dengan adanya pendidikan nilai-nilai multikultural dalampembentukan karakter religius pada siswa seperti yang tercantum di dalam UU Sistem Pendidikan Nasional No 20 Tahun 2003, Bab II Pasal 3. Jadi, pendidikan nilai-nilai multikultural dalam pembentukan karakter religius pada siswa itu penting, karena dapat mewujudkan peserta didik agar menjadi manusia yang beriman dan bertakwa kepada Tuhan Yang Maha Esa, berakhlak mulia, dan menjadi warga negara yang demokratis serta bertanggung jawab.

Sementara itu, nilai-nilai multikultural perlu ditanamkan di lingkup lembaga pendidikan atau sekolah, karena Indonesia merupakan salah satu negara yang multikultural.Keberagaman ini, diakui atau tidak, dapat menimbulkan berbagai persoalan, seperti contohnyapremanisme, perseteruan politik, kemiskinan, kekerasan, seperatisme, perusakan lingkungan dan rasa hilangnya kemanusiaan untuk selalu menghormati hak-hak orang lain. ${ }^{3}$ Bahkan berbagai persoalan tersebut juga terjadi dalam dunia pendidikan atau sekolah, contohnya saja kekerasan yang terjadi di sekolah.Bentuk kekerasan yang terjadi di sekolah cukup beragam, seperti kasus yang ditangani oleh Komisi Perlindungan Anak Indonesia (KPAI) yang meliputi, kekerasan fisik, seksual, verbal, psikis,

\footnotetext{
${ }^{2}$ Syaiful Sagala, Manajemen Strategik dalam Peningkatan Mutu Pendidikan (Bandung: Alfabeta, 2010), hlm. 55.

${ }^{3}$ M. Ainul Yaqin, Pendidikan Multikultural : Cross-cultural Understanding untuk Demokrasi dan Keadilan (Yogyakarta: Nuansa Aksara, 2005), hlm. 4.
}

dan cyber bullying. ${ }^{4} \quad$ Serangkaian persoalan yang muncul dalam lingkungan sekolah tersebut terjadi karena akhlak siswa yang buruk sehingga belum dapat menerima keberagaman yang terjadi di sekitarnya. Sehingga sangat penting untuk dilakukan pembentukan karakter religius melalui pendidikan nilai-nilai multikultural pada siswa.

Oleh karena itu, serangkaian proses manajemen perlu dilakukan untuk melakukan upaya pendidikan nilai-nilai multikultural dalam pembentukan karakter religius pada siswa di lingkungan sekolah. Upaya tersebut diwujudkan melalui pendidikan, karena melalui pendidikanlah yang dapat membentuk watak dasar, intelektual dan emosi seseorang dalam melihat realitas yang ada di sekelilingnya. Ini dapat diartikan bahwa pendidikan merupakan proses mentransmisikan kebudayaan dan sekaligus pembelajaran norma-norma kemasyarakatan, melalui metode-metode tertentu sehingga orang memperoleh pengetahuan, pemahaman, dan cara bertingkah laku yang sesuai dengan kebutuhan. ${ }^{5}$

\section{B. LANDASAN TEORETIS \\ 1. Pengertian Manajemen Pendidikan Nilai-nilai Multikultural}

Pengertian manajemen pendidikan dalam bukunya Syaiful Sagala dapat diartikan sebagai berikut;

Proses dari instansi yang memimpin dan membimbing penyelenggaraan pekerjaan sekolah sebagai suatu organisasi dalam mewujudkan tujuan pendidikan dan tujuan sekolah yang telah ditetapkan. Karena itu prinsip-prinsip manajemen sekolah yang dapat dipegang adalah

\footnotetext{
${ }^{4}$ http://www.kpai.go.id/berita/kpai-quo-vadisperlindungan-anak-di-sekolah-antara-norma-danrealita, diakses tanggal 2 Februari 2017.

${ }^{5}$ Rahmi Fhoma, Internalisasi Nilai-nilai Multikultural, dalam, Yurdi Hasan (ed), Multikulturallisme: Menuju Pendidikan Berbasis Multikultural (Banda Aceh: YAB, 2011), hlm. 33.
} 
memperoleh hasil yang paling efektif melalui orang-orang yang professional yang mengacu pada visi dan misi sekolah dengan jalan melakukan proses manajemen, yakni menjalankan fungsi pokok program sekolah yang ditampilkan oleh seorang manajer atau pimpinan sekolah sebagai penanggung jawab pelayanan belajar pada peserta didik, dan tenaga kependidikan sebagai penangungg jawab pelayanan teknis kependidikan di sekolah yang menerapkan fungsi-fungsi manajemen yaitu: perencanaan (planning) program kegiatan sekolah, pengorganisasian (organizing) tugas-tugas pokok sekolah, penggerakan (actuating) seluruh sistem sekolah, dan pengawasan (controlling) kinerja sekolah. ${ }^{6}$

Jika ditarik kesimpulan dari pengertian Syaiful Sagala tersebut, maka manajemen dalam pendidikan yaitu proses mewujudkan tujuan pendidikan dan tujuan sekolah, yang mengacu kepada visi dan misi sekolah, yang dilakukan oleh manajer atau pimpinan sekolah dan tenaga kependidikan, yang penyelesaiannya memalui tahapan perencanaan program kegiatan sekolah, pengoraganisasian tugas-tugas pokok sekolah, penggerakan seluruh sistem sekolah, dan pengawasan kinerja sekolah.

Sedangkan pengertian pendidikan nilai-nilai multikultural terbagi menjadi dua pengertian yaitu pendidikan nilai dan pendidikan multikultural. Pendidikan nilai yaitu terdiri dari dua kata, yaitu pendidikan dan nilai. Pengertian pendidikan sendiri menurut Naquib AlAtas, yaitu:

Suatu proses penanaman sesuatu ke dalam diri mansuia. Maksud dari serangkaian pengertian pendidikan tersebut yaitu "suatu proses penanaman" mengacu pada metode dan sistem untuk menanamkan apa yang disebut sebagai "pendidikan" secara bertahap. Kata

\footnotetext{
${ }^{6}$ Syaiful Sagala, Manajemen Strategik dalam Peningkatan Mutu Pendidikan...,hlm. 55.
}

"sesuatu" mengacu pada kandungan yang ditanamkan, dan "diri manusia" mengacu pada penerima proses kandungan itu. ${ }^{7}$

Jika ditarik kesimpulan, konsep pendidikan menurut Naquib Al-Atas yaitu metode dan sistem untuk menanamkan apa yang disebut sebagai pendidikan secara bertahap, yang memiliki suatu kandungan untuk ditanamkan kepada diri siswa atau peserta didik. Sedangkan pengertian nilai yaitu menurut Muhammad Fathurrohman, merupakan suatu keyakinan atau kepercayaan yang menjadi dasar bagi seseorang atau sekelompok orang untuk memilih tindakannya atau menilai suatu yang bermakna atau tidak bermakna bagi kehidupannya. $^{8}$ Jadi, dapat ditarik kesimpulan dari pengertian pendidikan dan nilai tersebut, maka pendidikan nilai yaitu metode dan sistem untuk menanamkan suatu keyakinan atau kepercayaan yang menjadi dasar bagi seseorang atau sekelompok orang untuk menentukan tindakan yang diinginkannya atau menilai suatu yang bermakna atau tidak bermakna, yang sifatnya untuk membedakan individu atau antar kelompok yang satu dengan yang lainnya. Pengertian pendidikan multikulturaldalam bukunya Muhammad Thabroni dan Arif Mustafa, yang mendefinisikan pendidikan multikultural sebagai berikut:

Pendidikan multikultural merupakan sebuah kebijakan sosial yang didasarkan pada prinsip-prinsip pemeliharaan budaya dan saling memilliki rasa hormat antara seluruh kelompok budaya di dalam masyarakat. Pembelajaran multikultural pada dasarnya merupakan program pendidikan bangsa agar komunitas

\footnotetext{
${ }^{7}$ Syed Muhammad Al-Naquib Al-Attas, Konsep Pendidikan dalam Islam terj. Haidar Bagir (Bandung: Mizan, 1984), hlm. 35.

${ }^{8}$ Muhammad Fathurrohman, Budaya Religius dalam Peningkatan Mutu Pendidikan (Yogyakarta: Kalimedia, 2015), hlm. 54
} 
multikultural dapat berpartisipasi dalam mewujudkan kehidupan demokrasi yang ideal bagi bangsanya.

Jadi, multikultural dalam pendidikan atau pendidikan multikultural merupakan suatu kegiatan untuk mewujudkan kehidupan demokrasi yang ideal bagi suatu bangsa, dimana kebijakan-kebijakan sosialnya yang dipakai yaitu harus berdasarkan prinsip-prinsip saling menghormati antar kelompok budaya yang ada di masyarakat suatu bangsa tersebut.Jadi, dengan demikian ditarik kesimpulan bahwa pendidikan multikultural merupakan proses yang dapat diartikan sebagai proses pengembangan sikap dan tata laku seseorang atau sekelompok orang dalam usaha mendewasakan manusia melalui upaya pengajaran, pelatihan, proses, perbuatan, dan cara-cara mendidik yang memerhatikan keragaman budaya yang dimiliki oleh setiap peserta didik.

Jika ditarik kesimpulan, maka pengertian pendidikan nilai-nilai multikultural yaitu merupakan proses menanamkan suatu keyakinan atau kepercayaan untuk mengembangan sikap dan tata laku seseorang atau sekelompok orang dalam usaha mendewasakan manusia melalui upaya pengajaran, pelatihan, proses, perbuatan, dan cara-cara mendidik yang memerhatikan keragaman budaya yang dimiliki oleh setiap peserta didik. Pendidikan nilai-nilai multikultural dilakukan untuk mewujudkan kehidupan demokrasi yang ideal bagi suatu bangsa, supaya masyarakat yang ada bisa saling menghormati satu sama lain.

Pengertian manajemen pendidikan nilai-nilai multkultural dapat ditarik kesimpulan dari keseluruhan pengertianpengertian di atas,yaitupemanfaatan sumber daya manusia yang ada di sekolah,

\footnotetext{
${ }^{9}$ Muhammad Thabroni dan Arif Mustafa, Belajar dan Pembelajaran: Pengembangan Wacana dan Praktik Pembelajaran dalam Pembangunan Nasional (Yogyakarta: Ar-Ruzz Media, 2011), hlm. 396.
}

yaitu manajer atau pimpinan sekolah dan tenaga kependidikan, untuk menanamkan suatu keyakinan atau kepercayaan untuk mengembangan sikap dan tata laku siswa atau sekelompok siswa dalam usaha untuk mendewasakan siswa melalui upaya pengajaran, pelatihan, proses, perbuatan, dan cara-cara mendidik yang memerhatikan keragaman budaya yang dimiliki oleh setiap siswa. Manajemen pendidikan nilai-nilai multikultural dilakukan melalui beberapa tahapan, yaitu perencanaan, penggerakan, dan pengawasan. Manajemen pendidikan nilai-nilai multikultural memiliki tujuan untuk mewujudkan kehidupan demokrasi yang ideal bagi suatu bangsa, supaya masyarakat yang ada bisa saling menghormati satu sama lain.

\section{Nilai-nilai Multikultural dalam Pendidikan}

Menurut Abdullah Aly terdapat kesesuaian antara nilai-nilai multikultural dalam perspektif Barat dengan nilai-nilai multikultural dalam perspektif Islam. Namun demikian, sumber kebenaran dari nilai-nilai multikultural tersebut berbeda. Jika nilai-nilai multikultural dalam perspektif Barat bersumber dari filsafat yang bertumpu pada hak-hak asasi manusia, maka nilai-nilai multikultural dalam perspektif Islam bersumber dari wahyu. $^{10}$ Akan tetapi, nilai-nilai yang terkandung dalam muatan nilai-nilai multikultural yang sejalan dengan prinsip Islam dan dapat diimplementasikan atau ditanamkan dalam Pendidikan adalah sebagai berikut:

a. Kesetaraan

Kesetaraan adalah suatu sikap mengakui adanya persamaan derajat, persamaan hak, dan persamaan

\footnotetext{
${ }^{10}$ Abdullah Aly, Pendidikan Islam Multikultural di Pesantren(Yogyakarta: Pustaka Pelajar, 2011),hlm. 124
} 
kewajiban sebagai sesama manusia. Satu-satunya pembedaan kualitatif dalam pandangan Islam adalah ketakwaan. Pada waktu melakukan ibadah haji terakhir Nabi Muhammad SAW membuat pernyataan dengan etika global. Dalam sebuah hadis diriwayatkan olej Al-Adda' bin Khalid dalam Al-Thabari's al-Mu'jam alKabir: "Wahai umat manusia, semua orang berasal dari Adam sedang Adam dari ekstrak tanah. Orang Arab tidak lebih mulia daripada non-Arab, orang kulit hitam, kecuali karenaa kelebihan ketaqwaannya" (HR. Abu Hurairah). Hal ini membuktikan bahwa Islam tidak membeda-bedakan perlakuan terhadap seseorang berdasarkan ras, agama, etnis, suku, ataupun kebangsaannya, hanya ketakwaan seseoranglah yang membedakannya di hadapan Sang Pencipta. ${ }^{11}$

b. Keadilan

Konsep keadilan yang membongkar budaya nepotisme dan sikap-sikap korup, baik dalam politik, ekonomi, hukum, hak dan kewajiban, bahkan dalam praktek-praktek keagamaan. Al-Qur'an memerintahkan agar berlaku adil terhadap siapapun. Seperti yang tercantum dalam Q.S AnNisa : 58, yaitu "Jangan sampai kebencian terhadap suatu kaum itu mendorong untuk tidak berlaku adil".Jadi, adil harus dilakukan terhadap diri sendiri, keluarga, kelompok, dan juga terhadap lawan. ${ }^{12}$

Konsep keadilan yang menjadi landasan pendidikan multikultural secara sederhana mencoba memberikan perlakuan yang sama yaitu perlakuan yang sama terhadap semua peserta didik. Selayaknya, dalam pendidikan

\footnotetext{
${ }^{11}$ Salmiwati, "Urgensi Pendidikan Agama Islam dalam Pengembangan Nilai-nilai Multikultural" Jurnal Al-Ta'lim, Jilid I, Nomor 4 Februari 2013, hlm. 339.

${ }^{12}$ Ibid.
}

semua peserta didik mendapatkan perlakuan yang sama, yaitu secara konstitusi dijelaskan dalam Undangundang Sisdiknas yang menyatakan "Pendidikan diselenggarakan secara demokratis dan berkeadilan serta tidak diskriminatif dengan menjunjung tinggi hak asasi manusia, nilai kultural, dan kemajemukan bangsa."13

c. Demokrasi atau kebebasan

Konsep demokrasi memandang semua manusia pada hakikatnya hamba Tuhan saja, sama sekali bukan hamba sesama manusia. Berakar dari konsep ini, maka manusia dalam pandangan Islam mempunyai kemerdekaan dalam memilih profesi, memilih wilayah hidup, bahkan dalam menentukan pilihan agamapun tidak dapat dipaksa, seperti tercantum dalam Q.S Al Baqarah: 256 yang artinya,

Tidak ada paksaan untuk (memasuki) agama (Islam); Sesungguhnya telah jelas jalan yang benar daripada jalan yang sesat, karena itu Barangsiapa yang ingkar kepada Taghut dan beriman kepada Allah, Maka sesungguhnya ia berpegang kepada buhul tali yang amat kuat yang tidak akan putus, dan Allah Maha mendengar lagi Maha mengetahui. ${ }^{14}$

Demokrasi sesungguhnya adalah seperangkat gagasan dan prinsip tentang kebebasan, tetapi juga menyangkut seperangkat praktek dan prosedur yang terbentuk melalui sejarah panjang dan berliku. Singkatnya demokrasi adalah pelembagaan dari kebebasan. ${ }^{15}$

13 Undang-undang SISDIKNAS, No. 20 Tahun 2003, Bab III, Prinsip Penyelenggaraan Pendidikan, Pasal 4.

${ }^{14}$ Salmiwati, "Urgensi Pendidikan Agama Islam dalam Pengembangan Nilai-nilai Multikultural",.., hlm. 339.

15 Mulyana, Demokrasi dalam Budaya Lokal (Yogyakarta: Tiara wacana, 2005), hlm. 5. 
Pendidikan multikultural mendambakan proses pendidikan yang berjalan dengan sistem dan alur nuansa yang demokratik. Demokrasi dalam pendidikan sama saja memberikan kebebasan dalam berfikir, kebebasan berekspresi, kebebsan berkretifitas, serta bebas menentukan arah minat peserta didik.

Demokrasi memiliki nilai-nilai, antara lain kebebasan, hak-hak individu, tujuan bersama, keadilan dan patriotisme. Sebagai salah satu nilai demokrasi, kesadaran akan keadilan dalam kehidupan bermasyarakat perlu untuk ditanamkan dalam diri setiap siswa. Sudah barang tentu kesadaran itu terkait dengan materi pembelajaran yang terdapat diberbagai macam mata pelajaran tertentu, tetapi lebih penting daripada itu, kesadaran dan keadilan sangat terkait dengan perilaku guru dalam melaksanakan pembelajaran. Pendidik atau guru senantiasa harus melaksanakan pembelajaran yang mampu mencerahkan dan membangkitkan keingintahuan dan semangat siswa untuk mengidentifikasi berbagai faktor yang menghambat pengembangan potensi yang dimiliki secara optimal dan pengembangan kebebasan yang mereka miliki. ${ }^{16}$

d. Toleransi

Konsep toleransi yang merupakan kemampuan untuk menghormati sifat dasar, keyakinan, dan perilaku yang dimiliki oleh orang lain. Toleransi juga dipahami sebagai sifat atau sikap menghargai, membiarkan, atau membolehkan pendirian (pandangan) orang lain yang bertentangan dengan pandangan kita. Toleransi dalam pergaulan hidup antar umat beragama bukanlah toleransi dalam masalah-masalah keagamaan,

${ }^{16}$ Zamroni, Pendidikan Demokrasi pada Masyarakat Multikultural (Yogyakarta: Gavin Kalam Utama, 2011), hlm. 127. melainkan perwujudan sikap keberagamaan pemeluk suatu agama dalam pergaulan hidup antara orang yang tidak seagama, dalam masalahmasalah kemasyarakatan atau kemaslahatan umum. ${ }^{17}$

\section{Pelaksanaan Manajemen Pendidikan Nilai-nilai Multikultural}

Pelaksanaan manajemen pendidikan nilai-nilai multikultultural dapat dirumuskan melalui fungsi manajemen. Terkait dengan fungsi manajemen, terdapat beberapa tokoh manajemen yang berbeda pendapat dalam menentukan fungsi atau bagian apa saja yang harus ada dalam manajemen. Namun, dalam bukunya Imam Machali dan Ara Hidayat disebutkan bahwa secara umum perbedaan-perbedaan tersebut mempunyai titik temu dalam menyebutkan fungsi manajemen, yaitu: perencanaan, pengorganisasian, penggerakan dan pengawasan. $^{18}$ Jika fungsi manajemen tersebut dikaitkan dengan pendidikan nilai-nilai multikultural, maka penjelasannya sebagai berikut:

a. Perencanaan dalam pendidikan nilainilai multikultural

Pengertian perencanaan dalam bukunya Imam Machali dan Ara Hidayat, yaitu merupakan fungsi yang paling awal dari keseluruhan fungsi manajemen. Perencanaan adalah proses kegiatan yang menyiapkan secara sistematis kegiatan-kegiatan yang akan dilakukan untuk mencapai tujuan tertentu. ${ }^{19}$ Jadi ketika akan mencapai suatu tujuan tertentu yang sudah dirumuskan sebelumnya, maka harus

\footnotetext{
${ }^{17}$ Salmiwati, "Urgensi Pendidikan Agama Islam dalam Pengembangan Nilai-nilai Multikultural"..., hlm. 339.

${ }^{18}$ Imam Machali dan Ara Hidayat, The Handbook of Education Management: Teori dan Praktik Pengelolaan Sekolah/Madrasah di Indonesia (Jakarta: Prenada Media, 2016), hlm. 16.

${ }^{19}$ Ibid., hlm. 19.
} 
disusun kegiatan-kegiatan apa saja yang akan dilakukan untuk mencapainya, proses rangkaian penyusunan kegiatan-kegiatan inilah yang disebut dengan perencanaan.

Hal senada juga dijelaskan oleh Suharsimi Arikunto, yaitu "perencanaan adalah suatu proses mempersiapkan serangkaian keputusan untuk mengambil tindakan di masa yang akan datang yang diarahkan kepada tercapainya tujuan-tujuan dengan sarana yang optimal." 20 Pengertian perencanaan menurut Suharsimi Arikunto tidak jauh berbeda dengan pengertian perencanaan dalam bukunya Imam Machali dan Ara Hidayat di atas.

Langkah-langkah

dalam membuat perencanaan, sebagai berikut:

1) Memandang proses sebagai rangkaian pertanyaan yang harus dijawab.

2) Memandang proses perencanaan sebagai masalah yang harus dipecahkan secara ilmiah dan didasarkan pada langkah-langkah tertentu.

Karena dipandang proses merupakan suatu rangkaian pertanyaan yang harus dijawab, maka harus memuat beberapa pertanyaan, meliputi:

(1) apa (what), mengenai tujuan dan kegiatan yang akan dilaksanakan; (2) mengapa (why), mengenai keperluan atau alasan suatu kegiatan dilakukan; (3) bagaimana (how), mencakup sistem dan tata kerja; (4) kapan (when), mencakup masalah waktu dan penetapan prioritas kegiatan; (5) di mana (where), mengenai tempat berlangsung

20 Suharsimi Arikunto dan Lia Yuliana, Manajemen Pendidikan (Yogyakarta: Aditya Media, 2008), hlm. 9. kegiatan; dan (6) siapa (who), mengenai tenaga kerja. ${ }^{21}$

Jadi, untuk merumuskan suatu perencanakan harus memuat beberapa rangkaian pertanyaan yaitu yang mengandung unsur $5 \mathrm{~W}+1 \mathrm{H}$.

Oleh karena itu, dapat disimpulkan bahwa perencanaan dalam pendidikan nilai-nilai multikultural harus memuat beberapa rangkaian pertanyaan yang mengandung unsur $5 \mathrm{~W}+1 \mathrm{H}$. Jadi, dari $5 \mathrm{~W}+1 \mathrm{H}$ tersebut berarti yang pertama, memuat pertanyaan apa (what) yaitu membahas mengenai tujuan dan kegiatan yang akan dilaksanakan untuk menanamkan pendidikan nilai-nilai multikultural. Kedua, mengapa (why) yaitu membahas mengenai keperluan atau alasan pendidikan nilai-nilai multikultural perlu dilaksanakan. Ketiga, bagaimana (how) yang membahas cakupan sistem dan tata kerja yang akan dilaksanakan dalam pendidikan nilai-nilai mulitkultural. Keempat, kapan (when) yaitu mencakup masalah waktu dan penetapan prioritas kegiatan pendidikan nilai-nilai multikultural. Kelima, di mana (where) yaitu membahas mengenai tempat berlangsungnya kegiatan; dan yang terakhir keenam, siapa (who) yaitu membahas mengenai siapa saja yang menyusun atau melaksanakan perencanaan tersebut.

Jika dijabarkan dari beberapa rangkaian pertanyaan $5 \mathrm{~W}+1 \mathrm{H}$ di atas, maka perencanaan pendidikan nilainilai multikulural memiliki tujuan dan kegiatan yang dapat diwujudkan ke dalam bentuk program-program yang dapat terintegrasi melalui kurikulum dan sistem pembelajaran yang nantinya akan dilaksanakan oleh para stakeholder yang tedapat di sekolah.

\footnotetext{
${ }^{21}$ Imam Machali dan Ara Hidayat, The Handbook of Education Management..., hlm. 20-21.
} 
Alasannya yaitu karena kurikulum memiliki posisi yang sangat penting bagi pendidik dan tenaga kependidikan dalam menanamkan pendidikan nilainilai multikultural untuk membentuk karakter dan prestasi siswa di sekolah sesuai dengan dasar, fungsi, dan tujuan yang ingin dicapai oleh Undangundang Sistem Pendidikan Nasional No. 20 Tahun 2003. Hal tersebut, dikarenakan di dalam kurikulum terdapat seperangkat rencana dan aturan yang digunakan sebagai pedoman untuk mencapai tujuan pendidikan tertentu, hal ini telah disebutkan dalam pengertian kurikulum yang terdapat di UU Sisdikas No. 20 Tahun 2003 yang menyebutkan bahwa kurikulum merupakan "seperangkat rencana dan pengaturan mengenai tujuan, isi, dan bahan pelajaran serta cara yang digunakan sebagai pedoman penyelenggaraan kegiatan pembelajaran untuk mencapai tujuan pendidikan tertentu."22 Selain kurikulum yang memiliki posisi penting dalam pendidikan nilai-nilai multikultural, tedapat pula sistem pembelajaran dan kepribadian guru yang juga memainkan peran yang jelas dan penting dalam pembangunan untuk mendukung kepercayaan dan prestasi siswa di sekolah.

Setelah membahas programprogram yang akan dilaksanakan dan telah memiliki alasan yang cukup jelas tersebut, kemudian dalam tahap perencanaan pendidikan nilai-nilai multikultural selanjutnya yaitu membahas mengenai cakupan sistem dan tata kerja yang akan dilaksanakan dalam kurikulum dan sistem pembelajaran. Kurikulum saat ini yang digunakan oleh sebagian besar sekolah merupakan kurikulum 2013, yang di

\footnotetext{
${ }^{22}$ Undang-undang No. $20 \quad$ Tahun 2003 tentangSistem Pendidikan Nasional dan Penjelasannya, hlm. 3.
}

dalamnya mencakup empat kompetensi inti (KI), yaitu kompetensi inti sikap spiritual, sikap sosial, pengetahuan, dan keterampilan. Kompetensi inti pada kurikulum 2013 merupakan tingkat kemampuan untuk mencapai standar kompetensi lulusan yang harus dimiliki seorang peserta didik pada setiap tingkat kelas. ${ }^{23}$ Jika dilihat dari Permendikbud RI No. 69 tahun 2013, kurikulum 2013 di Sekolah Menengah Atas / Madrasah Aliyah memiliki kerangka dasar kurikulum dan struktur kurikulum sebagai acuannya. Kerangka dasar kurikulum Sekolah Menengah Atas / Madrasah Aliyah merupakan landasan filosofis, sosiologis, psikopaedagosis, dan yuridis yang berfungsi sebagai acuan pengembangan struktur kurikulum pada tingkat nasional dan pengembangan muatan lokal pada tingkat daerah serta pedoman pemengambangan kurikulum pada Sekolah Menengah Atas / Madrasah Aliyah. Sedangkan struktur kurikulum Sekolah Menengah Atas / Madrasah Aliyah merupakan pengorganisasian kompetensi inti, mata pelajaran, beban belajar, dan kompetensi dasar pada setiap Sekolah Menengah Atas / Madrasah Aliyah. ${ }^{24}$ Sedangkan melalui sistem pembelajaran, guru harus membuat atau menciptakan kegiatan di dalam dan di luar kelas, seperti belajar kelompok dan kunjungan lapangan. Jenis kegiatan yang mengharuskan adanya interaksi antar siswa atau interaksi siswa dengan orang-orang baru yang ada disekitarnya, melalui

\footnotetext{
${ }^{23}$ Permendikbud RI No 24 Tahun 2016 tentang Kompetensi Inti dan Kompetensi Dasar Pelajaran pada Kurikulum 2013 (Jakarta: Dirjen Peraturan Perundang-undangan Kemenkumham RI, 2016), hlm. 4.

${ }^{24}$ Permendikbud RI No. 69 Tahun 2013 tentang Kerangka Dasar dan Struktur Kurikulum Sekolah Menenggah Atas/Madrasah Aliyah (Jakarta: Menkumham, 2013), hlm. 2.
} 
kegiatan tersebut diharapkan dapat menanamkan pendidikan nilai-nilai multikultural secara langsung terhadap siswa. $^{25}$ Jadi, kurikulum merupakan petunjuk (guide) yang harus dikuasi oleh pendidik atau guru, sehingga seorang pendidik perlu untuk membuat sebuah susunan rencana pelaksanaan pembelajaran (RPP), dan melalui sistem pembelajaran seorang pendidik atau guru harus kreatif dengan melibatkan siswa secara aktif.

Perencanaan dalam pendidikan nilai-nilai multikultural yang terintegrasi melalui kurikulum dan sistem pembelajaran dapat diterapkan kepada peserta didik melalui kegiatan belajar mengajar di kelas serta di lingkungan sekolah. Kurikulum dan sistem pembelajaran harus dikuasai terutama oleh pendidik karena pendidik berperan sebagai transfer of knowledge kepada peserta didik. Perencanaan dalam menerapkan kurikulum dan sistem pembelajaran di sekolah disusun oleh kepala sekolah beserta wakilwakilnya, dan kemudian dilaksanakan oleh seluruh pendidik serta tenaga kependidikan lainnya yang ada di sekolah yang nantinya pelaksanaannya harus dapat dipertanggungjawabkan kepada kepala sekolah selaku manajer yang ada di sekolah.

b. Pengorganisasian dalam pendidikan nilai-nilai multikultural

Pengorganisasian merupakan lanjutan dari fungsi perencanaan dalam sebuah sistem manajemen. Pengorganisasian bisa dikatakan sebagai "urat nadi" bagi seluruh organisasi atau lembaga, oleh karena itu pengorganisasian sangat berpengaruh terhadap berlangsungnya suatu organisasi atau lembaga,

\footnotetext{
${ }^{25}$ Merfat Ayesh Alsubale, "Examples of Current Issues in the Multicultural Classroom", Journal of Education and Practice, No. 10, Vol. VI, 2015, hlm. 88 .
}

termasuk didalamya lembaga pendidikan. $^{26} \quad$ Pengorganisasian terdapat suatu arti penyatuan atau penghimpunan pikiran dan tenaga orang-orang yang tergabung dalam organisasi. ${ }^{27} \mathrm{Jadi}$, dapat ditarik kesimpulan, bahwa pengorganisasian sangat berpengaruh terhadap berlangsungnya suatu organisasi atau lembaga, yang didalamnya terdapat penyatuan atau penghimpunan pikiran dan tenaga orang-orang yang tergabung didalam suatu organisasi.

Pengorganisasian adalah suatu kegiatan pengaturan atau pembagian pekerjaan yang dialokasikan kepada sekelompok orang atau karyawan yang dalam pelaksanaannya diberikan tanggung jawab dan wewenang. Sehingga tujuan organisasi dapat tercapai secara efektif dan efisien, dan produktif. Sehingga tujuan organisasi dapat tercapai secara efektif, efisien, dan produktif. Pendidikan dapat berjalan dengan baik kalau semua anggota organisasinya dapat bekerjasama dengan baik. Oleh karena itu, perlu adanya pembagian tugas yang jelas antara kepala sekolah, staf pengajar, pegawai administrasi, komite sekolah, dan siswanya. ${ }^{28}$ Jika ditarik kesimpulan, supaya tujuan suatu sekolah atau lembaga pendidikan tercapai secara efektif, efisien, dan produktif, diperlukan adanya kerjasama yang baik, melalui pembagian tugas yang jelas antara kepala sekolah, staf pengajar, pegawai administrasi, komite sekolah, dan siswanya.

Jika ditarik kesimpulan, pengorganisasian dalam pendidikan

\footnotetext{
${ }^{26}$ Imam Machali dan Ara Hidayat, The Handbook of Education Management..., hlm. 20-21.

hlm. 21.

${ }^{27}$ Suharsimi Arikunto dan Lia Yuliana, Manajemen Pendidikan..., hlm. 10.

${ }^{28}$ Imam Machali dan Ara Hidayat, The Handbook of Education Management..., hlm. 20-21.
} 
nilai-nilai multikultral dilaksanakan supaya tujuan suatu sekolah atau lembaga pendidikan tercapai secara efektif, efisien, dan produktif, diperlukan adanya kerjasama yang baik, melalui pembagian tugas yang jelas antara kepala sekolah, staf pengajar, pegawai administrasi, komite sekolah, dan siswanya.Jadi, pengorganisasian dalam pendidikan nilai-nilai multikultural merupakan kelanjutan dari tahap perencanaan yang sudah dirumuskan. Selain perencanaan, pengorganisasian juga memerlukan unsur-unsur $5 \mathrm{~W}+1 \mathrm{H}$ untuk menjawab rangkaian proses pengorganisasian yang ada di sekolah. Pengorganisasian dalam pendidikan nilai-nilai multikultural dapat diwujudkan melalui pengoragnisasian yang jelas antara kepala sekolah, staf pengajar, pegawai administrasi, komite sekolah, dan siswa itu sendiri. Biasanya supaya lebih jelas dan terarah ranah kerjanya, di sekolah dibentuklah struktur organisasi yang terdapat nama-nama orang yang bertugas atau menempati posisi tertentu untuk melaksanakan tugasnya. Alasannya hal tersebut dilakukan karena untuk mencapai suatu tujuan sekolah yang efektif, efisien, dan produktif sangat diperlukan adanya kerjasama yang baik melalui pembagian tugas yang jelas.

c. Penggerakan dalam pendidikan nilainilai multikulural

Penggerakan (actuating) adalah salah satu fungsi manajemen yang berfungsi untuk merealisasikan hasil perencanaan dan pengorganisasian. Actuating adalah upaya untuk menggerakkan atau mengarahkan tenaga kerja (man power) serta mendayagunakan fasilitas yang ada yang dimaksud untuk melaksanakan pekerjaan secara bersama. Actuating dalam organisasi juga biasa diartikan sebagai keseluruhan proses pemberian motif bekerja kepada para bawahan sedemikian rupa sehingga mereka bersedia bekerja secara sungguhsungguh demi tercapainya tujuan organisasi. Fungsi penggerakan ini menempati posisi yang penting dalam merealisasikan segenap tujuan organisasi. Penggerakan mencakup di dalamnya, yaitu kepemimpinan, motivasi, komunikasi, dan bentukbentuk lain dalam rangka memengaruhi seseorang untuk melakukan sesuatu guna mencapai tujuan organisasi. Kepemimpinan berfungsi sebagai pemberi arahan, komando, dan pemberi serta pengambil keputusan oraganisai. Motivasi berguna sebagai cara untuk menggerakkan agar tujuan organisasi tercapai, sedangkan komunikasi berfungsi sebagai alat untuk menjamin hubungan dalam rangka fungsi penggerakkan dalam organisasi. ${ }^{29} \mathrm{Jadi}$, ditarik kesimpulan penggerakan yaitu pemberian motif bekerja kepada para bawahan sehingga mereka dapat bekerja dengan sungguh-sunguh demi tercapainya tujuan organisasi atau lembaga pendidikan, yang mencakup di dalamnya ada kepemimpinan, motivasi, komunikasi, dan bentuk-bentuk lain dalam rangka memengaruhi bawahan. Penggerakan sangat terkait dengan penggunaan berbagai sumber daya organisasi, oleh karenanya kemampuan memimpin, memberi motivasi, berkomunikasi, menciptakan iklim dan budaya organisasi yang kondusif menjadi kunci penggerakan. ${ }^{30}$

Jadi, penggerakan (actuating) adalah penggerakan yaitu pemberian motif bekerja kepada para bawahan sehingga mereka dapat bekerja dengan sungguh-sunguh demi tercapainya tujuan organisasi atau lembaga pendidikan, yang mencakup di dalamnya ada kepemimpinan, motivasi,

\footnotetext{
${ }^{29}$ Ibid., hlm.23

${ }^{30}$ Ibid., hlm. 23
} 
komunikasi, dan bentuk-bentuk lain dalam rangka memengaruhi bawahan. Jadi, melalui unsur $5 \mathrm{~W}+1 \mathrm{H}$,maka ditarik kesimpulan, bahwa penggerakan dalam pendidikan nilai-nilai multikultural diwujudkan ke dalam bentuk kegiatan yang sudah dirumuskan melalui tahap perencanaan sebelumnya, karena penggerakan memiliki posisi yang sangat penting dalam merealisasikan tujuan sekolah dalam menanamkan pendidikan nilainilai multikultural. Jadi, peran kepala sekolah sangat dibutuhkan untuk memberikan motif bekerja kepada para stakeholder yang ada di sekolah melalui kemampuannya dalam memimpin, memberikan motivasi, menjalin komunikasi, dan bentukbentuk lainnya untuk menanamkan pendidikan nilai-nilai multikultural dalam pembentukan karakter religius siswa.

d. Pengawasan dalam pendidikan nilainilai multikultural

Pengawasan adalah usaha pimpinan untuk mengetahui semua hal yang menyangkut pelaksanaan kerja, khususnya untuk mengetahui kelancaran kerja para pegawai dalam melakukan tugas mencapai tujuan. Kegiatan pengawasan sering juga disebut kontrol, penilaian, penilikan, monitoring, superfisi dan sebagainya. Tujuan utama pengawasan adalah supaya dapat diketahui tingkat pencapaian tujuan dan menghindarkan terjadinya penyelewengan. ${ }^{31}$ Oleh karena itu pengawasan dapat diartikan pengendalian.

Jadi, pengawasan dilakukan untuk mengetahui tingkat pencapaian tujuan yang telah dilakukan oleh para pegawai suatu lembaga dalam melaksanakan tugasnya. Kegiatan pengawasan biasanya juga disebut

\footnotetext{
${ }^{31}$ Suharsimi Arikunto dan Lia Yuliana, Manajemen Pendidikan..., hlm. 13-14.
}

dengan kontrol, penilaian, penilikan, monitoring, superfisi, dan sebagainya.Jika disimpulkan, maka pengawasan dalam pendidikan nilainilai multikultural di sekolah perlu dilaksanakan dengan alasan untuk mengetahui tingkat kelancaran kerja para stakeholder yang ada di sekolah dalam melaksanakan program-program yang sudah direncanakan dengan baik untuk mencapai visi, misi, dan tujuan sekolah terutama dalam menanamkan pendidikan nilai-nilai multiklutural untuk membentuk karakter religius pada siswa.

\section{Pendidikan Nilai-nilai Multikultural dalam KarakterReligius Pembentukan}

\section{a. Pengertian Karakter Religius}

Pengertian karakter menurut Herman Kertajaya adalah ciri khas yang dimiliki seseorang dan ciri khas tersebut adalah asli mengakar pada kepribadian seseorang tersebut, dan merupakan mesin pendorong bagaimana seseorang bertindak, bersikap, berujar dan merespon sesuatu. ${ }^{32}$ Sedangkan, menurut Winnie bahwa istilah karakter memiliki dua pengertian tentang karakter, pertama, ia menunjukkan bagaiman seseorang berperilaku tidak jujur, kejam atau rakus, tentulah seseorang tersebut memanifestasikan perilaku buruk. Sebaliknya apabila seseorang berperilaku jujur, suka menolong, tentulah orang tersebut memanifestasikan karakter mulia. Kedua, istilah karakter erat kaitannya dengan personality. Seseorang baru bisa disebut orang yang berkarakter

\footnotetext{
${ }^{32}$ Jamal Ma'mur Asmani, Buku Panduan Internalisasi Pendidikan Karakter di Sekolah (Yogyakarta: Diva Press, 2012), hlm. 28
} 
apabila tingkah lakunya sesuai dengan kaidah moral. ${ }^{33}$

Pengertian karakter didalam bukunya Abdul Majid dan Dian Andayani, adalah watak, sifat, atau halhal yang memang sangat mendsar yang ada pada diri seseorang. Hal-hal yang sangat abstrak yang ada pada diri seseorang. Sering orang menyebutnya dengan tabiat atau perangai. ${ }^{34}$

Jadi, karakter adalah kualias atau moral, akhlak, atau budi pekerti individu yang merupakan kepribadian khusus, yang menjadi pendorong dan penggerak, serta membedakannya dengan individu lain. Seseorang dapat dikatakan berkaarakter, jika telah berhasil menyerap nilai dan keyakinan dan dikehendaki masyarakat, serta digunakan sebagai moral dalam hidupnya.

Sedangkan religius biasa diartikan dengan kata agama. Agama adalah sistem kepercayaan yang senantiasa mengalami perubahan dan perkembangan sesuai dengan tingkat kognisi seseorang. Agama buukan hanya masalah spirit, melainkan telah terjadi hubungan intens antara agama sebagai sumber nilai dan agama sebagai sumber kognitif. ${ }^{35}$

Agama bukan hanya kepercayaan kepada yang ghaib dan melaksanakan ritual-ritual tertentu. Agama adalah keseluruhan tingkah laku manusia yang terpuji, yang dilakukan demi memperoleh ridha Allah. Agama dengan kata lain, meliputi keseluruhan

\footnotetext{
33 Heri Gunawan, Pendidikan Karakter Konsep dan Implementasi (Bandung: Alfabeta, 2012), hlm. 2.

${ }^{34}$ Abdul Majid dan Dian Andayani, Pendidikan Kakarter Perspektif Islam (Bandung: PT Remaja Rosdakarya, 2011), hlm. 12.

${ }^{35}$ Chusnul Chotimah dan Muhammad Fathurrohman, Komplemen Manajemen Pendidikan Islam: Konsep Integratif Pelengkap Manajemen Pendidikan Islam (Yogyakarta: Teras, 2014), hlm. 338.
}

tingkah laku manusia dalam hidup ini, yang tingkah laku itu membentuk keutuhan manusia berbudi luhur (berakhlaq karimah), atas dasar percaya atau iman kepada Allah dan tanggung jawab pribadi di hari kemudian. ${ }^{36}$ Jadi dalam hal ini, agama mencakup totalitas tingkah laku manusia dalam kehidupan sehari-hari yang dilandasi dengan iman kepada Allah, sehingga seluruh tingkah lakunya berlandaskan keimanan dan akan membentuk akhlak karimah yang terbias dalam pribadi dan perilakunya sehari-hari.

Menurut Muhaimin, kata religius tidak identik dengan kata agama, namun lebih kepada keberagaman. Keberagaman lebih melihat aspek yang di dalam lubuk hati nurani pribadi, sikap personal yang sedikit banyak misteri bagi orang lain, karena menafaskan intimitas jiwa, cita rasa yang mencakup totalitas ke dalam pribadi manusia. $^{37}$

Serangkaian penjelasan terkait religius di atas, jika ditarik kesimpulan maka karakter religius yaitu keseluruhan tingkah laku manusia yang terpuji dengan berlandaskan keimanan dan akan membentuk manusia berbudi luhur (ber-akhlaq karimah) yang terbias dalam pribadi dan perilakunya sehari-hari untuk memperoleh ridho Allah.Jadi dari pengertian karakter dan religius di atas, dapat ditarik kesimpulan bahwa karakter religius adalah kualitas atau moral, akhlak, atau budi pekerti individu yang merupakan keseluruhan tingkah laku manusia yang terpuji dengan berlandaskan keimanan dan akan membentuk manusia berbudi luhur (ber-akhlaq karimah) yang terbias dalam pribadi dan perilakunya

\footnotetext{
${ }^{36}$ Ibid., hlm. 339.

${ }^{37}$ Muhaimin dalam bukunya Muhammad Fathurrohman, Budaya Religius dalam Peningkatan Mutu Pendidikan (Yogyakarta: Kalimedia, 2015), hlm. 51.
} 
sehari-hari untuk memperoleh ridho Allah.

b. Pembentukan Karakter Religius

Pembentukan karakter religius yang diteliti oleh peneliti yaitu pada siswa Madrasah Aliyah Negeri (MAN). Karena siswa MAN merupakan siswa yang memasuki masa remaja, dalam tahap perkembangan karakter religius yang dikembangkan oleh Moran, dijelaskan bahwa masa remaja merupakan masa peralihan dari anak menuju dewasa. Selain perubahan biologis, anak mengalami perubahan kehidupan psikologi dan kehidupan sosio-budayanya, dan yang lebih penting lagi dunia lainnya, dunia penuh penemuan dan pengalaman yang bahkan ditingkatkannya menjadi eksperimentasi. Tidak jarang anak menghadapi ketidak jelasan, keraguan bahkan kadang-kadang seperti menemukan dirinya dalam dunia yang sama sekali baru dan asing. Jika dalam situasi seperti ini, tidak jarang dia harus menempuh langkahnya, yang kadang bersifat sejalan dan kadang-kadang berlawanan dengan apa yang telah terbiasa dilakukan sehari-hari, atau bahkan berlawanan dengan kebiasaaan atau tradisi yang berlaku, sehingga dia tampak menentang dan menantang arus. Pada saat ini dia memulai aktifitas penemuan sistem nilai, adakalanya dia suka mencoba-coba, bereksperimen seberapa jauh keberlakuan nilai tersebut. Karena perkembangan penalaran, pengalaman dan pendidikannya yang sudah memungkinkan untuk berpikir dan menimbang, bersikap kritis terhadap persoalan yang dihadapinya, maka tidak jarang dia menunjukkan sikap sinis terhadap pola tingkah laku atau nilai yang tidak setuju. Pada masa ini orang tua dan pendidik pada umumnya, perlu mengundangnya memasuki dunia religius dan menciptakan situasi agar dia betah mendiaminya. ${ }^{38}$

Agama bagi kebanyakan orang merupakan sebuah acuan utama yang membawa mereka untuk membentuk kehidupan yang bermoral yang bernilai religius. Meskipun agama memiliki banyak perbedaan mengenai apa yang harus dilakukan umatnya dalam beribadah, mereka semua memiliki kesamaan prinsip bahwa setiap tindakan yang mereka lakukan dalam hidup ini termasuk pilihan akan perilaku moral, akan memberikan dampak yang sebanding di masa yang akan datang. ${ }^{39}$

Sebuah organisasi masyarakat di Chicago yang menamakan diri For Character telah menjadi sponsor dalam program penganugerahan di bidang pendidikan dasar dan menengah yang telah mampu mendidik siswa-siswi mereka untuk dapat berprestasi baik dalam hal karakter maupun akademik. Sebuh survei yang dilakukan di sekolah-sekolah unggulan, termasuk beberapa sekolah yang berada di pinggiran yang berlokasi di lingkungan yang penuh dengan tindak kriminalitas, ternyata semua sekolah tersebut memiliki banyak hal serupa untuk membentuk karakter, yaitu : tujuan sekolah yang terbuka, ketegasan akademik, kedisiplinan yang konsisten dan adil, kepemimpinan yang handal, pengembangan terhadap nilai-nilai kekuatan yang berlaku di sekolah, dan sebuah penekanan dalam sebuah pencapaian yaitu kepedulian terhadap kesejahteraan masyarakat. ${ }^{40}$

\footnotetext{
${ }^{38}$ Abdul Latif, Pendidikan Berbasis Nilai Kemasyarakatan (Bandung: Refika Aditama, 2007), hlm. 76.

${ }^{39}$ Thomas Lickona, Educating for Character: How Our Schools Can Teach Respect and Responsibility terj. Juma Abdu Wamaungo (Jakarta:Bumi Aksara, 2013), hlm. 64.

${ }^{40}$ Ibid., hlm. 64.
} 
Pembentukan karakter religius yang dilaksanakan dalam kaitannya dengan pengembangan diri, dapat dilakukan melalui empat hal yang meliputi: ${ }^{41}$

1) Kegiatan rutin

Merupakan kegiatan yang dilaksanakan peserta didik secara terus menerus dan konsisten setiap saat. Misalnya upacara bendera setiap hari Senin, salam dan salim di depan pintu gerbang sekolah, piket kelas, salat berjamaah, berdoa sebelum dan sesudah jam pelajaran terakhir, berbaris saat masuk kelas, dan sebgainya.

2) Kegiatan spontan

Bersifat spontan, saat ituu juga, pada waktu terjadi keadaan tertentu, misalnya mengumpulkan sumbangan bagi korban bencana alam, mengunjungi teman yang sakit atau sedang tertimpa musibah, dan lain-lain.

3) Keteladanan

Timbulnya sikap dan perilaku peserta didik karena meniru perilaku dan sikap guru dan tenaga kependidikan di sekolah, bahkan perilaku seluruh warga sekolah yang dewasa lainnya sebagai model, termasuk misalnya petugas kantin, satpam sekolah, penjaga sekolah, dan sebagainya. Dalam hal ini akan dicontoh oleh siswa misalnya kerapian baju para pengajar, guru BK dan kepala sekolah, kebiasaan para warga sekolah untuk disiplin, tidak merokok, tertib dan teratur, tidak pernah terlambat masuk sekolah, saling peduli dan kasih sayang, perilaku yang sopan santun, jujur, dan biasa bekerja keras.

4) Pengondisian

\footnotetext{
${ }^{41}$ Muchlas Samani dan Hariyanto, Konsep dan Model Pendidikan Karakter (Bandung: PT Remaja Rosdakarya, 2012), hlm. 146-147.
}

Penciptaan kondisi yang mendukung keterlaksanaan karakter religius, misalnya kondisi meja guru dan kepala sekolah yang rapi, kondisi toilet yang bersih, disediakan tempat sampah yang cukup, halaman sekolah yang hijau penuh pepohonan, tidak ada puntung rokok di sekolah.

Karakter religius yang dibentuk harus memiliki komponen, komponenkomponen tersebut menurut Thomas Lickona, harus memuat moral knowing (pengetahuan moral), moral feeling (perasaan moral), dan moral action (tindakan moral). ${ }^{42}$ Penjelasannya sebaagai berikut;

1) Pengetahuan moral (moral knowing) Pengetahuan moral sebagai komponen pertama memiliki enam unsur, yaitu: kesadaran moral (moral awareness), pengetahuan tentang nilai-nilai moral (knowing moral values), penentuan perspektif (perspective taking), pemikiran moral (moral reasoning), pengambilan keputusan (decision making), dan pengetahuan pribadi (self knowledge). ${ }^{43}$

Keenam unsur ini adalah komponen-komponen yang harus diajarkan kepada siswa untuk mengisi ranah pengetahuan mereka. Hal tersebut dilakukan karena pembinaan pola pikir/kognitif, yakni pembinaan kecerdasan dan ilmu pengetahuan yang luas dan mendalam sebagai penjabaran dari sifat fathanah Rasulullah. Seseorang itu tidak saja cerdas, tetapi juga memiliki kebijaksanaan atau

\footnotetext{
${ }^{42}$ Thomas Lickona, Educating for Character: How Our Schools Can Teach Respect and Responsibility..., hlm. 84..

${ }^{43}$ Ibid., hlm. 85-89.
} 
kearifan dalam berpikir dan bertindak. $^{44}$

Tahapan ini tujuan diorientasikan pada penguasaan pengetahuan tentang nilai-nilai. Siswa harus mampu membedakan nilai-nilai akhlak mulia dan tercela serta nilai-nilai universal, memahami secara logis dan rasional (bukan secara dogmatis dan doktriner) pentingnya akhlak mulia dan bahaya akhlak tercela dalam kehiudupan, dan yang terakhir siswa mampu mengenal sosok Nabi Muhammad Saw. sebagai figur teladan akhlak mulia melalui hadishadis dan sunahnya. ${ }^{45}$

2) Perasaan moral (moral feeling)

$$
\text { Perasaan moral (moral }
$$
feeling) merupakan tingkat lanjut dari komponen pertama yaitu pengetahuan moral (moral knowing) yang menekankan aspek pengetahuan/kognitif, maka pada komponen kedua ini lebih ditekankan pada aspek perasaan/afektif. Perasaan moral sebagai komponen kedua memiliki enam unsur, yaitu: hati nurani (conscience), harga diri (selfesteem), empati (empathy), mencintai hal yang baik (loving the good), kendali diri (self-control), dan kerendahan hati (humility). ${ }^{46}$

Afektif yakni pembinaan sikap mental (mental attitude) yang mantap dan matang sebagai penjabaran dari sikap amanah Rasulullah. Indikator dari seseorang yang mempunyai kecerdasan ruhaniah adalah sikapnya yang

\footnotetext{
${ }^{44}$ Abdul Majid dan Dian Andayani, Pendidikan Karakter Perspektif Islam (Bandung: PT Remaja Rosdakarya, 2012), hlm. 31-32.

45 Ibid., hlm. 112

${ }^{46}$ Thomas Lickona, Educating for Character: How Our Schools Can Teach Respect and Responsibility..., hlm. 91-97.
}

selalu ingin menampilkan sikap yang ingin dipercaya (kredibel), menghormati dan dihormati. Sikap hormat dan dipercaya hanya dapat tumbuh apabila meyakini sesuatu yang dianggap benar sebagai prinsip-prinsip yang tidak dapat diganggu gugat. ${ }^{47}$

3) Tindakan moral (moral action) Setelah dua komponen tersebut terwujud, maka moral action sebagai outcome akan dengan mudah muncul dari para siswa. ${ }^{48}$ Meskipun demikian, ada masa ketika kita mungkin mengetahui apa yang harus kita lakukan, merasakan apa yang harus kita lakukan, namun masih gagal untuk menerjemahkan pikiran dan perasaan kita ke dalam tindakan. Untuk benar-benar memahami apa yang menggerakkan seseorang untuk melakukan tindakan moral atau mencegah seseorang untuk tidak melakukannya, perlu memerhatikan tiga unsur yaitu, kompetensi, keinginan, dan kebiasaan. ${ }^{49}$

Karakter religius dapat diwujudkan dalam berbagai sisi kehidupan manusia. Aktivitas beragama tidak hanya terjadi ketika seseorang melakukan perilaku ritual (beribadah), tetapi juga ketika melakukan aktivitas lain yang didorong oleh kekuatan supranatural. Bukan hanya yang berkaitan dengan aktivitas yang tampak dan dapat dilihat dengan mata, tetapi juga aktivitas yang tidak tampak dan terjadi dalam hati seseorang. Karena itu keberagamaan seseorang akan meliputi berbagai macam sisi dan dimensi.

Glock dan Stark dalam bukunya Muhaimin, menjelaskan bahwa agama

\footnotetext{
${ }^{47}$ Abdul Majid dan Dian Andayani, Pendidikan Karakter Perspektif Islam..., hlm. 33.

${ }^{48}$ Ibid., hlm. 36.

${ }^{49}$ Thomas Lickona, Educating for Character: How Our Schools Can Teach Respect and Responsibility..., hlm. 98-99
} 
adalah sistem simbol, sistem keyakinan, sistem nilai, dan sistem perilaku yang terlembagakan, yang semuanya itu berpusat pada persoalan-persoalan yang dihayati sebagai yang paling maknawi (ultimate meaning). Menurut Glock dan Strak ada lima macam dimensi religius atau keberagamaan, yaitu: ${ }^{50}$

a. dimensi keyakinan, yang berisi pengharapan-pengharapan yakni orang religius berpegang teguh pada pandangan teologis tertentu dan mengakui kebenaran doktrin tersebut.

b. dimensi praktik agama, yakni mencakup perilaku pemujaan, ketaatan, dan hal-hal lain yang dilakukan orang untuk menunjukkan komitmen terhadap agama yang dianutnya. Praktik-praktik keagamaan ini tterdiri dari dua kelas penting, yaitu ritual dan ketaatan.

c. dimensi pengalaman, yakni berisikan dan memperhatikan fakta bahwa semua agama mengandung pengharapanpengharapan tertentu, meski tidak tepat jika dikatakan bahwa seseorang yang beragama dengan baik pada suatu waktu akan mencapai pengetahuan subjektif dan langsung mengenai kenyataan terakhir bahwa ia akan mencapai suatu kontak dengan kekuatan supernatural. Dimensi ini berkaitan dengan pengalaman keagamaan, perasaan-perasaan, persepsi-persepsi dan sensasi-sensasi yang dialami seseorang.

Setelah mengetahui tentang pengertian karakter religius dan pembentukannya pada siswa, maka perlu diketahui bahwa kaitan antara pendidikan multikultural dengan karakter religius. Penjelasannya yaitu, munculnya berbagai pandangan dalam menyikapi berbagai perbedaan yang ada dari beberapa

\footnotetext{
${ }^{50}$ Muhaimin, Paradigma Pendidikan Islam: Upaya Mengefektifkan Pendidikan Agama Islam di Sekolah (Bandung: PT Remaja Rosdakarya, 2012), hlm. 293-294.
}

kelompok dalam kehidupan sesame muslim. Apalagi masyarakat Indonesia terdiri oleh mayoritas masyarakat Islam. Setidaknya masyarakat muslim yang konon katanya adalah masyarakat yang mencintai perdamaian menjadi tonggak utama dan tolak ukur dalam menggerakkan perdamaian dan kerukunan dalam kehidupan di dunia ini.

Pentingnya pendidikan nilai-nilai multikultural dalam membentuk karakter religius, karena karakter religius merupakan sikap dan perilaku yang patuh dalam memahami dan melaksanakan ajaran agama yang dianut, dalam hal ini juga termasuk sikap toleran terhadap aliran kepercayaan agama lain, serta hidup rukun dan berdampingan. ${ }^{51}$ Dalam hal ini juga diteladankan oleh Rasulullah ketika menjadi pemimpin politik dan agama di Madinah. Beliau memberikan hak dan jaminan yang sama bagi non-muslim selama tidak memusuhi Islam. Komitmen tersebut terangkum dalam Konstitusi Madinah dan Piagam Madinah. ${ }^{52}$

Melalui Piagam Madinah, Nabi telah meletakkan pondasi bagi kehidupan bernegara, terlebih bagi yang bermasyarakat majemuk, baik suku, ras, agama, dan lain sebagainya yang intinya sebagai berikut. Pertama, semua pemeluk Islam, walaupun berasal dari banyak suku, baik pendatang maupun penduduk asli Madinah merupakan satu komunitas. Kedua, hubungan antar sesama anggota komunitas Islam dan antara komunitas Islam dengan komunitas lain, didasarkan atas, 1) bertetangga baik; 2) saling membantu dalam menghadapi musuh

\footnotetext{
${ }^{51}$ Kementrian Pendidikan Nasional dikutip oleh Suyadi, Strategi Pembelajaran Pendidikan Karakter (Bandung: PT Remaja Rosdakarya, 2013), hlm. 8.

${ }^{52}$ Umi Sumbulah, dikutip dalam Tesis Ahmad Muzakkil Anam:"Penanaman Nilai-nilai Pendidikan Multikultural di Perguruan Tinggi: Studi Kasus di Universitas Islam Malang” (Malang: UIN Maulana Malik Ibrahim, 2016), hlm. 55 .
} 
bersama; 3) membela mereka yang teraniaya; 4) saling menasehati dan konsultasi; dan 5) menghormati kebebasan beragama. $^{53}$

Pendidikan nilai-nilai multikultural dalam konteks pendidikan di sekolah, perlu menjadi landasan utama penyelenggaraan proses belajar mengajar untuk membentuk karakter religius siswa. Masyarakat, guru, dan orang tua siswa perlu mengambil peran untuk membentuk karakter religius pada diri siswa. Sehingga mempromosikan konsep diri yang positif itu penting, sejauh itu difokuskan pada aktivitas-aktivitas yang menyinari keserupaan dan perbedaan dari semua siswa yang ada. Siswa dapat diajak untuk bermain peran sebagai sebuah strategi utama untuk mengembangkan perspektif baru tentang kebudayaan dan kehidupan. Perlakuan terhadap siswa sebagai individu yang unik, yang masing-masing dapat memberikan konstribusi khusus, adalah strategi yang jitu. Bila guru paham tentang dunia siswa, ia harus menyadari latar belakang kultural siswa. Siswa juga dapat memperoleh manfaat dari pemahaman tentang latar belakang dan warisan kultural gurunya. ${ }^{54}$ Untuk itu perlu kiranya agar inovasi dan reformasi kurikulum dalam pendidikan nilai-nilai multikultural tidak semata menyentuh proses pemindahan pengetahuan (transfer of knowledge), namun juga membagi pengalaman dan ketrampilan (sharing experience and skills). ${ }^{55}$

\section{Manajemen Pendidikan Nilai-nilai Multikultural dalam Pembentukan Karakter Religius Siswa}

\footnotetext{
${ }^{53}$ Munawir Sadzali, dikutip dalam Tesis Ahmad Muzakkil Anam:"Penanaman Nilai-nilai Pendidikan Multikultural di Perguruan Tinggi ...", hlm. 56.

${ }^{54}$ Zakiyuddin Baidhawy, Pendidikan Agama Berwawasan Mulltikultural(Jakarta: Erlangga, 2005), hlm. 39.

${ }^{55}$ Ibid., hlm.40.
}

Berbagai penjelasan terkait dengan manajemen dalam pendidikan, penanaman nilai-nilai multikultural dalam pendidikan, dan karakter religius yang sudah di jelaskan di atas, jika ditarik kesimpulan secara keseluruhan maka manajemen pendidikan nilai-nilai multikultural dalam pembentukan karakter religius siswa yaitu pemanfaatan sumber daya manusia yang ada di sekolah, yaitu manajer atau pimpinan sekolah dan tenaga kependidikan untuk menanamkan suatu keyakinan atau kepercayaan untuk mengembangkan sikap dan tata laku seseorang atau sekelompok orang dalam usaha mendewasakan manusia melalui upaya pengajaran, pelatihan, proses, perbuatan, dan cara-cara mendidik yang memerhatikan keragaman budaya yang dimiliki oleh setiap peserta didik untuk membentuk kualitas atau moral, akhlak, atau budi pekerti peserta didik yang merupakan keseluruhan tingkah laku yang terpuji dengan berlandaskan keimanan yang akan membentuk manusia berbudi luhur (ber-akhlaq karimah) yang terbias dalam pribadi dan perilakunya sehari-hari untuk memperoleh ridho Allah.

\section{METODE PENELITIAN \\ 1. Teknik Pengumpulan Data}

a. Wawancara

Peneliti melakukan wawancara dengan beberapa partisipan, dalam penentuan beberapa partisipan, peneliti menggunakan teknik purposive sampling dan snowball.Beberapa partisipan yang dijadikan sumber data diantaranya, yaitu:Kepala Madrasah MAN Yogyakarta III,Waka Madrasah bidang kurikulum, pengasuh asrama dan sebagai guru SKI di MAN Yogyakarta III,guru Akidah Akhlak,guru Bimbingan Konseling (BK), serta beberapa siswa.

b. Observasi

Observasi dalam penelitian ini dilakukan secara non partisipatif (Non- 
Participan Observation). Observasi non partisipatif berarti peneliti tidak ikut serta dalam kegiatan yang sedang berlangsung, tetapi peneliti hanya berperan mengamati kegiatan yang diperlukan. Observasi dilakukan untuk memperoleh data berupa gambaran tentang proses yang terjadi dalam pelaksanaan manajemen pendidikan nilai-nilai multikultural dalam pembentukan karakter religius siswa di MAN Yogyakarta III serta hasil yang didapatkan.

c. Dokumentasi

Teknik ini penulis gunakan untuk mendapatkan data tentang struktur organisasi, visi, misi, dan tujuan sekolah, serta keadaan di sekolah, dan kegiatan-kegiatan di sekolah yang terkait dengan manajemen pendidikan nilai-nilai multikulural dalam pembentukan karakter religius, dan foto-foto pendukung lainnya.

\section{Uji Validitas Data}

Penelitian ini menggunakan teknik trianggulasi data, untuk menguji keabsahan data.Trianggulasi yang dipakai dalam penelitian ini adalah trianggulasi teknik dan trianggulasi sumber.

\section{Teknik Analisis Data}

Penelitian inimenggunakan analisis data model interaktif, terdiri atas empat tahapan yang harus dilakukan, yaitu pengumpulan data, reduksi data, penyajian data, dan penarikan kesimpulan. ${ }^{56}$ Jadi dalam teknik analisis data, setelah peneliti melakukan pengumpulan data, kemudian peneliti melakukan reduksi data, maksudnya yaitu merangkum, memilih hal-hal pokok, memfokuskan pada hal-hal yang penting, dicari tema dan polanya dan

\footnotetext{
${ }^{56}$ Miles dan Huberman dalam Herdiansyah, Metodologi Penelitian Kualitatif untuk ilmu-ilmu sosial(Jakarta: Salemba Humanika, 2012), hlm. 164 .
}

membuang yang tidak perlu, ${ }^{57}$ data yang telah direduksi akan memberikan gambaran yang lebih jelas dan mempermudah peneliti untuk melakukan pengumpulan data selanjutnya dan mencarinya bila diperlukan. Kemudian setelah direduksi peneliti melakukan penyajian data, bentuknya berupa uraian singkat, bagan, keterkaitan antar kategori, flowchart dan sejenisnya serta dengan teks yang bersifat naratif. Setelah itu langkah yang terakhir yaitu penarikan kesimpulan, yang berarti kegiatan dengan maksud untuk menemukan makna diri, data yang telah disajikan, menghubungkan data yang satu dengan yang lain. Kesimpulan dalam penelitian ini diharapkan merupakan temuan baru yang sebelumnya belum pernah ada. Temuan dapat berupa deskripsi atau gambaran suatu objek yang sebelumnya masih remang-remang atau gelap sehingga setelah diteliti menjadi jelas, dapat berupa hubungan kasual atau interaktif, hipotesis atau teori.

\section{HASIL PENELITIAN}

Berdasarkan hasil analisis data dari wawancara, observasi, dokumentasi, dan data-data yang mendukung penelitian ini yang berkaitan dengan manajemen pendidikan nilai-nilai multikultural dalam pembentukan karakter religius siswa di MAN Yogyakarta III tahun pelajaran 2016/2017, maka hasil penelitian yang peneliti peroleh sebagai berikut:

1. Pelaksanaan manajemen pendidikan nilai-nilai multikultural di MAN Yogyakarta III meliputi:

a. Perencanaan, yang dilaksanakan melalui tiga tahap, yaitu dengan menentukan visi, misi, dan tujuan, menyelengggarakan rapat kerja, dan merencanakan program kerja dan berbagai kegiatan yang terintegrasi

\footnotetext{
${ }^{57}$ Sugiyono, Metode Penelitian Pendidikan: Pendekatan Kuantitatif, Kualitatif, dan $R \& D$ (Bandung: Alfabeta, 2009), hlm. 338.
} 
melalui kurikulum dan sistem pembelajaran yang berupa kegiatan intrakurikuler serta ekstrakurikuler.

b. Pengorganisasian, yang terdiri dari dua kelompok, yaitu kelompok orang-orang yang berpengaruh menjalankan roda organisasi, dan kelompok yang menjalankan keahliannya yang disebut staf.

c. Penggerakan, yang terdapat dua penggerakan, yang pertama penggerakan yang dilakukan oleh kepala madrasah terhadap seluruh pendidik dan tenaga kependidikan, melalui rapat koordinasi setiap hari Senin, dan rapat bulanan yang disebut dengan SIGMA. Kedua, penggerakan terhadap seluruh siswa yang dilakukan melalui berbagai program kegiatan yang dirumuskan, berbagai kegiatan yang terintegrasi melalui kurikulum dan sistem pembelajaran di madrasah berupa kegiatan intrakurikuler dan ekstrakurikuler, serta ditanamkan melalui berbagai pembiasaan di asrama (boarding).

d. Pengawasan di Mayoga dibagi menjadi dua bentuk, yaitu pengawasan dari dalam (internal) dan pengawasan dari luar (ekstrenal).

2. Implementasi pendidikan nilai-nilai multikultural dalam pembentukan karakter religius siswa di Mayoga yaitu terdiri dari:

a. Kegiatan rutin, yaitu diterapkan melalui pembiasaan-pembiasaan di madrasah, melalui berbagai program kegiatan di madrasah, dan pembiasaan yang dilakukan di asrama.

b. Kegiatan insidental, yaitu melalui kegiatan yang diadakan pada waktu terjadinya keadaan tertentu.

c. Pengondisian, yaitu adanya berbagai papan tulisan yang tergantung di setiap lorong madrasah yang memuat kalimat memotivasi, serta kondisi toilet dan lingkungan madrasah yang bersih dan hijau.

\section{E. SIMPULAN}

Hasil penelitian ini menunjukkan bahwa yang pertama, dalam pelaksanaan manajemen pendidikan nilai-nilai multikultural di MAN Yogyakarta III meliputi empat tahap, yaitu perencanaan yang dilaksanakan melalui tiga proses, pengorganisasian yang terdiri dari dua kelompok, penggerakan yang terdiri dari dua bentuk penggerakan, dan pengawasan yang dibagi menjadi dua bentuk pengawasan.

Kedua, implementasi nilai-nilai pendidikan multikulural dalam pembentukan karakter religius dilakukan melalui tiga proses yaitu kegiatan rutin yang diterapkan melalui tiga kegiatan, kegiatan spontan yang diadakan pada waktu tertentu, dan pengondisian yang diterapkan melalui berbagai tulisan yang memotivasi.

\section{DAFTAR PUSTAKA}

Al-Attas, Syed Muhammad Al-Naquib, Konsep Pendidikan dalam Islam terj. Haidar Bagir, Bandung: Mizan, 1984.

Ahmad Muzakkil Anam, "Penanaman Nilai-nilai Pendidikan Multikultural di Perguruan Tinggi: Studi Kasus di Universitas Islam Malang", Tesis UIN Maulana Malik IbrahimMalang, 2016.

Aly, Abdullah, Pendidikan Islam Multikultural di Pesantren, Yogyakarta: Pustaka Pelajar, 2011.

Arikunto, Suharsimi dan Lia Yuliana, Manajemen Pendidikan, Yogyakarta: Aditya Media, 2008. 
Asmani, Jamal Ma'mur, Buku Panduan Internalisasi Pendidikan Karakter di Sekolah, Yogyakarta: Diva Press, 2012.

Chotimah, Chusnul dan Muhammad Fathurrohman, Komplemen Manajemen Pendidikan Islam: Konsep Integratif Pelengkap Manajemen Pendidikan Islam, Yogyakarta: Teras, 2014.

Fathurrohman, Muhammad, Budaya Religius dalam Peningkatan Mutu Pendidikan, Yogyakarta: Kalimedia, 2015.

Fhoma, Rahmi, Internalisasi Nilai-nilai Multikultural, dalam, Yurdi Hasan (ed), Multikulturallisme: Мenuju Pendidikan Berbasis Multikultural, Banda Aceh: YAB, 2011.

Gunawan, Heri, Pendidikan Karakter Konsep dan Implementasi, Bandung: Alfabeta, 2012.

Kementrian Pendidikan Nasional dikutip oleh Suyadi, Strategi Pembelajaran Pendidikan Karakter, Bandung: PT Remaja Rosdakarya, 2013.

Latif, Abdul, Pendidikan Berbasis Nilai Kemasyarakatan, Bandung: Refika Aditama, 2007.

Lickona, Thomas, Educating for Character: How Our Schools Can Teach Respect and Responsibility terj. Juma Abdu Wamaungo, Jakarta:Bumi Aksara, 2013.

Machali, Imam dan Ara Hidayat, The Handbook of Education Management: Teori dan Praktik Pengelolaan Sekolah/Madrasah di Indonesia, Jakarta: Prenada Media, 2016.
Majid, Abdul dan Dian Andayani, Pendidikan Kakarter Perspektif Islam, Bandung: PT Remaja Rosdakarya, 2011.

Merfat Ayesh Alsubale, "Examples of Current Issues in the Multicultural Classroom", Journal of Education and Practice, No. 10, Vol. VI, 2015.

Miles dan Huberman dalam Herdiansyah, Metodologi Penelitian Kualitatif untuk ilmu-ilmu sosial, Jakarta: Salemba Humanika, 2012.

Muhaimin, Paradigma Pendidikan Islam: Upaya Mengefektifkan Pendidikan Agama Islam di Sekolah, Bandung: PT Remaja Rosdakarya, 2012.

Mulyana, Demokrasi dalam Budaya Lokal, Yogyakarta: Tiara wacana, 2005.

Permendikbud RI No 24 Tahun 2016 tentang Kompetensi Inti dan Kompetensi Dasar Pelajaran pada Kurikulum 2013, Jakarta: Dirjen Peraturan Perundang-undangan Kemenkumham RI, 2016.

Permendikbud RI No. 69 Tahun 2013 tentang Kerangka Dasar dan Struktur Kurikulum Sekolah Menenggah Atas/Madrasah Aliyah, Jakarta: Menkumham, 2013.

Sagala, Syaiful, Manajemen Strategik dalam Peningkatan Mutu Pendidikan, Bandung: Alfabeta, 2010.

Salmiwati, "Urgensi Pendidikan Agama Islam dalam Pengembangan Nilainilai Multikultural" Jurnal AlTa'lim, Jilid I, Nomor 4 Februari 2013. 
Samani, Muchlas dan Hariyanto, Konsep dan Model Pendidikan Karakter, Bandung: PT Remaja Rosdakarya, 2012.

Sugiyono,Metode Penelitian Pendidikan: Pendekatan Kuantitatif, Kualitatif, dan $R \& D$, Bandung: Alfabeta, 2009.

Thabroni, Muhammad dan Arif Mustafa, Belajar dan Pembelajaran: Pengembangan Wacana dan Praktik Pembelajaran dalam Pembangunan Nasional, Yogyakarta: Ar-Ruzz Media, 2011.

Usman, Husaini, Manajemen: Teori Praktik dan Riset Pendidikan Ed. 2, Jakarta: Bumi Aksara, 2008.
Undang-undang SISDIKNAS, No. 20 Tahun 2003, Bab III, Prinsip Penyelenggaraan Pendidikan, Pasal 4.

Yaqin, M. Ainul, Pendidikan Multikultural : Cross-cultural Understanding untuk Demokrasi dan Keadilan, Yogyakarta: Nuansa Aksara, 2005

Zamroni, Pendidikan Demokrasi pada Masyarakat Multikultural, Yogyakarta: Gavin Kalam Utama, 2011.

http://www.kpai.go.id/berita/kpai-quovadis-perlindungan-anak-disekolah-antara-norma-dan-realita, diakses tanggal 2 Februari 2017. 